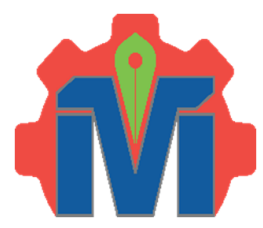

JMI Vol. 38 No. 2 Desember 2016

METAL INDONESIA

Journal homepage:

http://www.jurnalmetal.or.id/index.php/jmi

p-issn: $0126-3463$

e-issn : 2548-673X

\title{
PERANCANGAN RANGKA KENDARAAN MESIN PEMANEN JAGUNG KOMBINASI TERHADAP FAKTOR KEAMANAN
}

\section{DESIGNING FRAME OF MINI COMBINE CORN HARVESTER FOR SAFETY FACTORS}

\author{
Martin Doloksaribu, Sony Harbintoro, Agus Juniawan Khairi, Sina Jamilah \\ Balai Besar Logam dan Mesin, Kementerian Perindustrian \\ Jl Sangkuriang No. 12 Bandung 40135 \\ Email: mrtn.ds@gmail.com
}

\begin{abstract}
Abstrak
Pada penelitian ini dilakukan perancangan desain rangka untuk mesin kombinasi pemanen jagung tipe snapping roll-auger thresher. Desain melingkupi bentuk rangka, bentuk profil penyusun rangka dan ketebalan profil. Rangka didesain menggunakan profil kanal C, tubular dan hollow square bar dengan ketebalan $5 \mathrm{~mm}$. Penilaian (scoring) dan simulasi dilakukan untuk menentukan desain rangka yang optimal. Penilaian kemudahan fabrikasi dianalisa secara kuantitatif. Simulasi pembebanan, berat sasis, dan safety factor (SF) dilakukan terhadap desain rangka. Analisa kuantitatif kemudahan fabrikasi memberikan nilai 7, 7 dan 10 terhadap bentuk profil kanal C, tubular dan squre. Analisis pada desain rangka dengan kanal $\mathrm{C}$ memberikan berat $107 \mathrm{~kg}$, tegangan maksimum $46 \mathrm{MPa}$, deformasi maksimum $0,079 \mathrm{~mm}$ dan SF 5,43. Untuk tubular adalah $46 \mathrm{~kg}, 112 \mathrm{MPa}, 0,492 \mathrm{~mm}$ dan SF 2,23. Untuk square adalah $76 \mathrm{~kg}, 55 \mathrm{MPa}, 0,151 \mathrm{~mm}$ dan SF 4,55. Desain rangka dengan profil square section merupakan desain rangka dengan tingkat kemudahan fabrikasi paling baik dan memiliki perpaduan berat dan SF yang optimal.
\end{abstract}

Kata kunci: mesin pemanen jagung kombinasi, desain rangka, profil, kemudahan fabrikasi, safety factor

\begin{abstract}
Frame of corn harvester machine with snapping roll-auger-type thresher type was designed. Scopes of design were frame form, bar shape and bar thickness. Frame was designed with C-channel bar, hollow tubular bar and hollow square bar with $5 \mathrm{~mm}$ thickness. Scoring and simulation were performed to determine the optimal design, however scoring of fabrication level was given. Simulation of load distribution, weight and safety factor for each bar shape had been done. Scoring level offabrication for $C$-channel bar, tubular bar and square bar were 7, 7 and 10 respectively. Simulation of frame design with C-channel were $107 \mathrm{~kg}$ weight, $46 \mathrm{MPa}$ maximum stress, $0.079 \mathrm{~mm}$ maximum deformation and $5.43 \mathrm{SF}$. For tubular were $46 \mathrm{~kg}, 112 \mathrm{MPa}, 0.492 \mathrm{~mm}$ and $2.23 \mathrm{SF}$. For square were $76 \mathrm{~kg}, 55 \mathrm{MPa}$, $0.151 \mathrm{~mm}$ and $4.55 \mathrm{SF}$. Square hollow bar frame provides medium level of fabrication and optimal combination for weight and $S F$.
\end{abstract}

Keywords: combine corn harvester, chassis design, shape of bar, fabricaition level, safety factor

\section{PENDAHULUAN}

Data statistik BPS dan Kementerian Pertanian menunjukkan bahwa pada tahun 2015 (angka ramalan) akan dibutuhkan impor jagung pipilan sebanyak 1,7 juta ton (Direktur Jenderal Tanaman Pangan 2015). Kebutuhan jagung pipilan paling besar untuk pakan dan untuk keperluan industri. Kebutuhan impor dapat diturunkan dengan meningkatkan produksi jagung pipilan dalam negeri. Peningkatan produksi jagung pipilan dicapai dengan meningkatkan produktivitas (kuintal per hektar) jagung pipilan. Jika dengan jumlah lahan yang tetap dan siklus tanam yang tetap (sekitar $60 \mathrm{~s} / \mathrm{d}$ 150 hari sejak benih ditanam) maka salah satu cara peningkatan produktivitas adalah dengan memperkecil waktu panen sehingga lahan dapat ditanam jagung kembali. Penggunaan mesin panen dapat mempercepat durasi proses panen. 
Mekanisasi pertanian merupakan salah satu program prioritas pemerintah melalui Kementerian Pertanian. Kebijakan penyediaan dan pengembangan alat mesin pertanian (alsintan) tertuang dalam Peraturan Menteri Pertanian Nomor 03/Permentan/OT.140/2/2015 tentang Pedoman Upaya Khusus (Upsus) Peningkatan Produksi Padi, Jagung dan Kedelai. Melalui Program Perbaikan Jaringan Irigasi dan Sarana Pendukungnya Tahun Anggaran 2015. Dengan penyediaan alsintan kepada petani, pemerintah menargetkan swasembada padi-jagung-kedele (pajale) tercapai dalam kurun waktu 3 (tiga) tahun.

Sampai saat ini penyediaan alsintan dilakukan dengan cara impor. Namun alsintan impor tidak dapat langsung berfungsi optimal terhadap karakter pengguna, lahan dan jagung di Indonesia. Oleh karena itu perlu dilakukan beberapa penyesuaian desain terhadap kondisi pengguna, lahan dan jagung.

Desain mesin pemanen jagung kombinasi (combine corn harvester) akan dirancang sesuai dengan karateristik pengguna, lahan dan jagung di Indonesia. Desain konsep mesin ini adalah sebuah mesin yang dapat melakukan fungsi memetik, memipil, memisahkan dan menampung jagung pipilan. Desain diawali dengan mendesain bagian sasis (rangka/frame).

Perancangan desain konsep mesin panen jagung mengikuti model yang sudah ada. Desain konsep mesin panen jagung kombinasi dirancang menyerupai Corn Harvester yang ditemukan oleh Meier et al (Meier, Ott, and Haake 1984) dan mesin panen jagung produksi Republik Rakyat Tiongkok (RRT).

Mesin panen jagung dirancang terdiri dari modul pemanen dan sasis. Modul pemanen berfungsi sebagai pemanen yang terdiri dari modul pemetik pemetik, modul pemipil dan wadah penampung. Sasis berfungsi sebagai carrier dan sumber daya yang terdiri dari rangka (frame), engine, sistem pengereman, sistem kemudi dan sistem transmisi.

Rangka merupakan tulang punggung dari mesin pemanen. Oleh karena itu rangka harus mampu menerima gaya tekan dan gayagaya lainnya tanpa mengalami deformasi. Nilai yield stress material penyusun rangka harus lebih besar dari design stress (beban yang diterima pada aplikasi) sehingga rangka aman untuk dipakai. Nilai perbandingan tersebut (safety factor) tergantung dari kebutuhan.
Rangka sasis mobil Jeep dengan gross vehicle weight dan berat ladder frame ditentukan sebesar 3,6 ton $(35316 \mathrm{~N})$ disimulasi pada nilai safety factor (SF) 3 (Francis et al. 2014). Mild steel, aluminum alloy dan titanium alloy dapat digunakan sebagai material penyusun. Tushar M. Patel et al. merekomendasikan nilai SF untuk sasis rangka truk sebesar 1,5 2 (T. M. Patel, Bhatt, and Patel 2013) dengam material penyusun rangka adalah ST 52.

Penentuan besar safety factor ditentukan sesuai kondisi/kebutuhan. Maciej Szulc meneliti metode untuk menentukan safety factor terhadap rangka baja struktural pada kendaraan agrukultur (Szulc, Malujda, and Talaśka 2016). Safety factor untuk beban statik meliputi design accuracy (1 1,5), non-typical overload $(1,1 \sim 1,18)$ dan overload factor $(1,1 \sim 1,2)$.

Safety factor dipengaruhi oleh kekuatan rangka. Rangka harus kuat namun ringan. Berat rangka dapat dikurangi dengan memvariasikan dimensi profil beam atau menggunakan proses produksi alternatif. Variasi panjang, lebar, tebal terhadap cross section dapat mengoptimasi berat rangka (H. Patel, Panchal, and Jadav 2013). Mengubah ketebalan dan posisi lintangan (cross member) dapat memperbaiki desain (Hemant B.Patil, Sharad D.Kachave, and Eknath R.Deore 2013). Sin Liang Lin menggunakan tubehydroformed product untuk mengurangi berat rangka dan biaya pembuatan rangka (Lin, Huang, and Chen 2014).

Tata Truck 407 Chassis dibuat dari structural steel dengan tensile yield strength 2,5 x $10^{8} \mathrm{~Pa}$, UTS $4,6 \times 10^{8} \mathrm{~Pa}$ dan gross vehicle weight capacity $5700 \mathrm{~kg}$. Material lain untuk rangka adalah E-glass (tensile yield strength $2500 \mathrm{MPa}$ ). Material E-glass lebih ringan daripada steel dan lebih kaku.

Salvi Gauri Sanjay et al. melakukan stress analysis pada TATA 407 Fire Truck Chassis dengan material rangka adalah carbon fiber yield stress $200 \mathrm{MPa}$, modulus Young $190000 \mathrm{MPa}$, densitas $1570 \mathrm{~kg} / \mathrm{m}^{3}$ ). Carbon fiber lebih ringan 60-68\% dan memberikan kekakuan (Sanjay et al. 2014).

Variasi bentuk profil mempengaruhi kekuatan rangka. Dengan I cross section, nilai Von Misses stress menurun, safety factor meningkat dan berat rangka menurun dibandingkan $C$ cross section (Tayade and Patil 2015).

Finite Element Analysis dengan ANSYS merupakan metode yang dipakai untuk mensimulasikan stress analysis. Chen 
Yanghong et al. mensimulasikan stress analysis pada rangka heavy duty truck (Chen and Zhu 2011). Rangka YJ3128-type dump truck untuk angkutan di area pertambangan dianalisa menggunakan material $16 \mathrm{MnL}$ dengan SF 1,2. Hasil analisa adalah distribusi beban yang diterima rangka, besar beban maksimum dan area beban maksimum.

Beberapa area pada rangka akan mendapat beban maksimum. Penelitan Madhu Ps et al. menyebutkan bahwa maksimum Von Misses stress dan maksimum shear stress terjadi pada dekat bagian sambungan antara side beam dan cross beam (Ps and Venugopal 2014). Penelitian Roslan Abd Rahman et al. menyebutkan bahwa critical stress terjadi pada bagian yang dekat dengan baut. Area tersebut menjadi inisiasi retakan.

Proses perancangan awal perlu memperhatikan kemudahan untuk pengembangan. Perancangan desain rangka secara standar (modular) akan mempermudah pengembangan selanjutnya (Al-Zaher and ElMaraghy 2014).

Penelitian ini akan mendesain rangka untuk mesin panen kombinasi jagung (combine corn harvester) sesuai dengan karateristik lahan dan pengguna di Indonesia. Rangka dikembangkan untuk mesin pemanen jagung dengan modul snapping roll-auger thresher.

\section{METODOLOGI}

Metode perancangan rangka terhadap safety factor dapat dilihat pada Gambar 1 . Permodelan 3D rangka menggunakan software Pro Engineer. FEA disimulasikan menggunakan ANSYS. Ketebalan profil adalah $5 \mathrm{~mm}$. Material rangka adalah structural steel dengan density $7850 \mathrm{~kg} / \mathrm{m}^{3}$; tensile yield strength $250 \mathrm{MPa}$; ultimate tensile strength $460 \mathrm{MPa}$.

Design requirement yang menjadi batasan yaitu lahan jagung yang relatif kecil; dimensi (panjang-lebar) untuk 2 baris tanaman jagung; berat total mesin $2000 \mathrm{~kg}$ (tipe sedang); kemiringan operasi (slope) lahan 8/100; besar SF minimal adalah 2 (dua); desain rangka mudah difabrikasi.

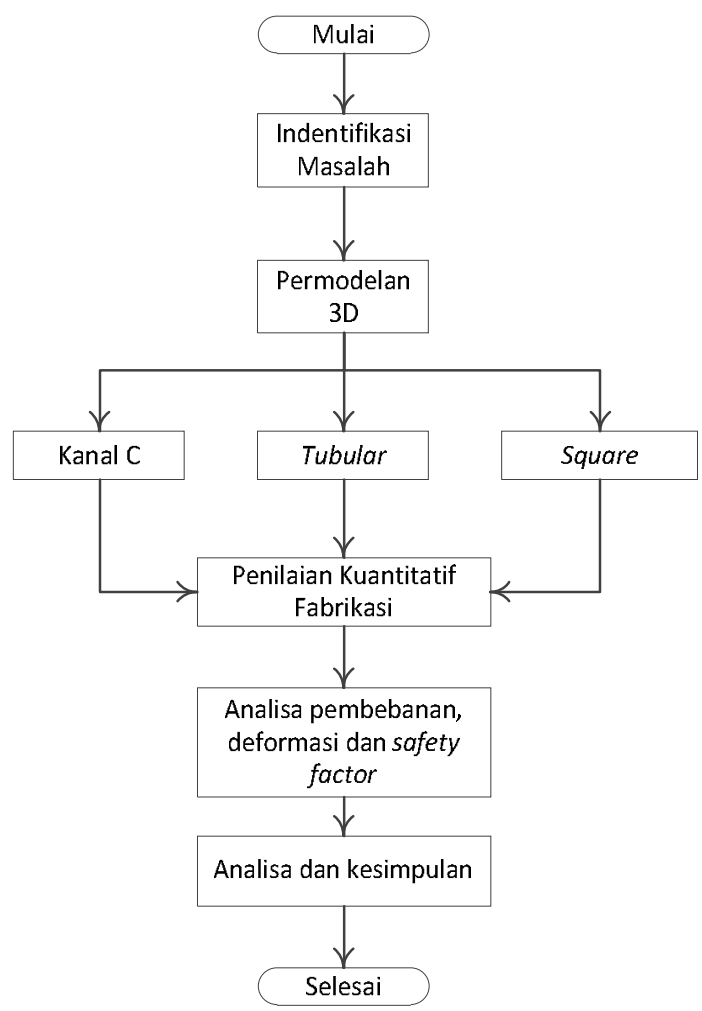

Gambar 1. Flowchart metodologi penelitian

Titik-titik pembebanan ditentukan sesuai layout penempatan engine, modul pemetik (header) dan modul perontok. Ketiga kompoenen tersebut memberikan kontribusi berat yang signifikan.

\section{PERANCANGAN SASIS}

Pada tahap awal dilakukan indentifikasi masalah dan kebutuhan (requirements). Desain konsep sesuai design requirements ditunjukkan pada Tabel 1 .

Model rangka yang dipilih adalah ladder frame, karena model rangka tersebut sederhana sehingga dalam proses manufaktur lebih menguntungkan dan sesuai dengan fungsi yang diperlukan.

Rangka dibuat dengan variasi 3 tipe profil: C-channel, hollow tubular dan hollow square bar.

Desain konsep rangka ditunjukkan Gambar 2. Panjang rangka adalah $4040 \mathrm{~mm}$. Lebar bagian depan yaitu $600 \mathrm{~mm}$ dan bagian belakang $200 \mathrm{~mm}$. 
Tabel 1. Design requirements dari desain konsep mesin kombinasi pemanen jagung

\begin{tabular}{|c|l|c|c|}
\hline No & \multicolumn{1}{|c|}{ Parameter } & Nilai & Satuan \\
\hline 1. & Lebar & 1560 & $\mathrm{~mm}$ \\
\hline 2. & Panjang & 4000 & $\mathrm{~mm}$ \\
\hline 3. & Putaran snapping roll & \pm 400 & $\mathrm{rpm}$ \\
\hline 4. & Putaran auger header & \pm 800 & $\mathrm{rpm}$ \\
\hline 5. & $\begin{array}{l}\text { Putaran auger } \\
\text { thresher }\end{array}$ & \pm 800 & $\mathrm{rpm}$ \\
\hline 6. & $\begin{array}{l}\text { Daya engine } \\
\text { (minimal) } \\
\text { Berat engine }\end{array}$ & 24 & $\mathrm{PK}$ \\
\hline 7. & Jenis bahan bakar & $\mathbf{5} 280$ & $\mathrm{Kg}$ \\
\hline 8. & $\begin{array}{l}\text { Kapasitas bahan } \\
\text { bakar }\end{array}$ & 10 & $\mathrm{liter}$ \\
\hline 9. & Berat modul & \pm 1000 & $\mathrm{~kg}$ \\
\hline 10. & Berat unit kendaraan & \pm 1000 & $\mathrm{~kg}$ \\
\hline 11. & Berat keseluruhan & \pm 2000 & $\mathrm{~kg}$ \\
\hline 12. & Ground clearence & $250 \sim 290$ & $\mathrm{~mm}$ \\
\hline 13. & Roda pengggerak & Depan \\
\hline
\end{tabular}

sisinya pada bagian pertemuan antara segmen dapat dilas. Gambar 3 menunjukkan rangka dengan $C$-channel.

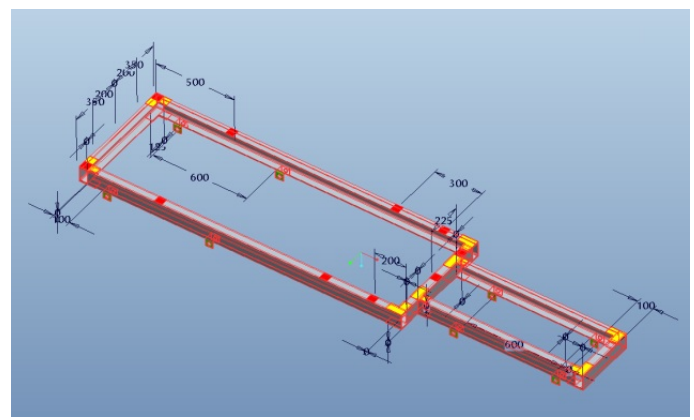

Gambar 3. Rangka varian pertama dengan profil C-channel

Rangka varian kedua menggunakan profil tubular section. Rangka tersebut ringan dan lentur. Proses cutting plane-nya rumit terhadap penempatan posisi garis pengelasan. Gambar 4 menunjukkan rangka varian kedua.

\begin{tabular}{|c|l|c|c|}
\hline 14. & Radius putar & 3 & $\mathrm{~m}$ \\
\hline 15. & $\begin{array}{l}\text { Safety Factor } \\
\text { (minimal) }\end{array}$ & 2 & \\
\hline
\end{tabular}

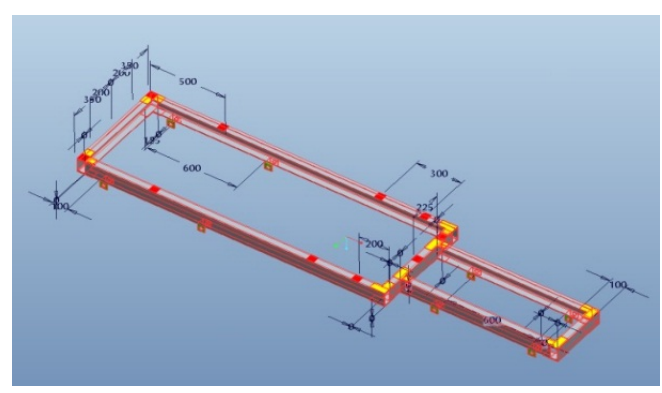

Gambar 2. Desain konsep rangka mesin pemanen jagung

\section{Analisa kemudahan fabrikasi terhadap kekuatan-kelenturan}

Rangka varian pertama dibuat dengan profil C-channel. Rangka tersebut kokoh dengan kelenturan medium. Pada proses pengelasan (fabrikasi), tidak semua bagian cutting planenya dapat bertemu sehingga tidak semua

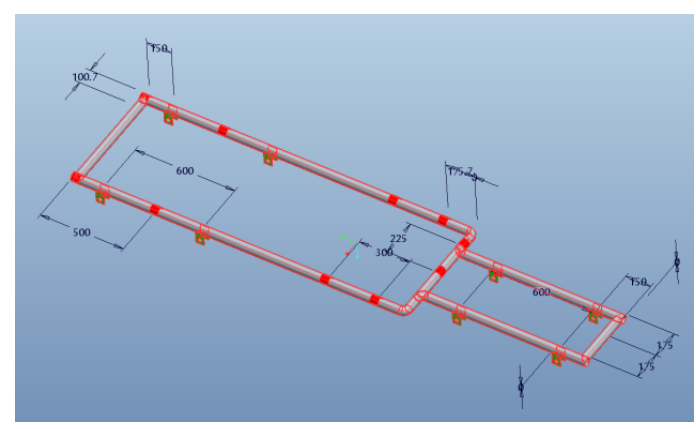

Gambar 4. Rangka varian kedua dengan profil tubular

Rangka varian ketiga menggunakan profil hollow square bar. Rangka tersebut kokoh dan rigid. Proses cutting plane mudah karena garis pengelasan dapat bertemu pada semua bagian pertemuan antara potongan. Rangka varian ketiga ditunjukkan Gambar 5. 


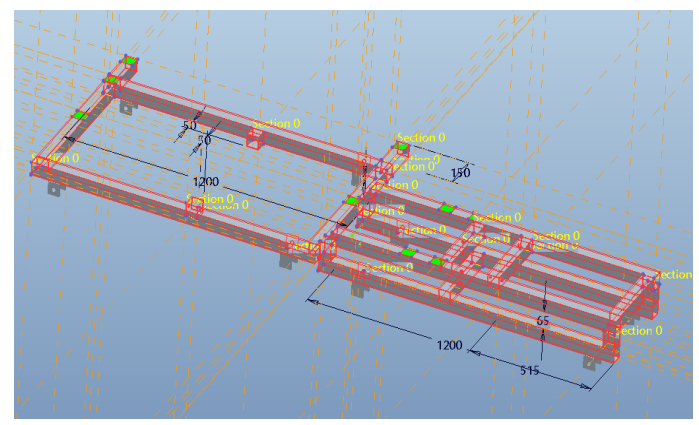

Gambar 5. Rangka varian ketiga dengan profil hollow square bar

Hasil penilaian (scoring) ketiga varian ditunjukkan Tabel 2.

Tabel 2. Scoring ke-3 varian bentuk profil terhadap kemudahan fabrikasi, kekuatan dan kelenturan

\begin{tabular}{|c|l|c|c|c|}
\hline \multirow{2}{*}{ No } & \multirow{2}{*}{ Parameter } & \multicolumn{3}{|c|}{ Bentuk Profil } \\
\cline { 3 - 5 } & & C-channel & $\begin{array}{c}\text { Hollow } \\
\text { Tubular }\end{array}$ & $\begin{array}{c}\text { Hollow } \\
\text { Square }\end{array}$ \\
\hline 1 & Cutting plane & 2 & 1 & 3 \\
\hline 2 & Garis pengelasan & 1 & 2 & 3 \\
\hline 3 & Kelenturan & 2 & 3 & 1 \\
\hline 4 & Kekuatan struktur & 2 & 1 & 3 \\
\hline & & $\mathbf{7}$ & $\mathbf{7}$ & $\mathbf{1 0}$ \\
\hline
\end{tabular}

Keterangan : $1=$ kurang, $2=$ sedang, $3=$ baik. Skor semakin besar $=$ semakin mudah fabrikasi

\section{HASIL DAN PEMBAHASAN} Simulasi pembebanan terhadap deformasi dan $\mathbf{S F}$

Simulasi ini untuk memprediksi kinerja rangka terhadap beban statis. Besar beban adalah 1300 kg. Posisi titik pembebanan ditunjukkan pada Gambar 6 (warna merah dan kuning). Tanda panah merah menunjukkan arah pembebanan.

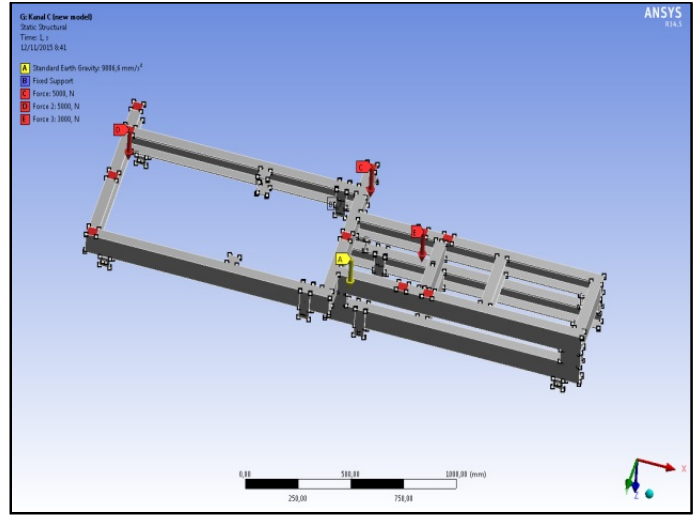

Gambar 6. Posisi titik-titik pembebanan pada rangka dengan $C$-channel

Analisa pembebanan pertama dilakukan terhadap rangka dengan profil $C$-channel section (Gambar 6). Berat rangka adalah $107 \mathrm{~kg}$. Distribusi/sebaran pembebanan ditunjukkan Gambar 7. Beban maksimal yang diterima oleh rangka sebesar $46 \mathrm{MPa}$. Distribusi besar pembebanan ditampilkan melalui gradasi dan perbedaan warna. Area dengan warna biru muda menunjukkan beban yang lebih besar dibandingkan area berwarna biru tua. Area yang menerima beban lebih besar antara lain bagian sudut depan rangka.

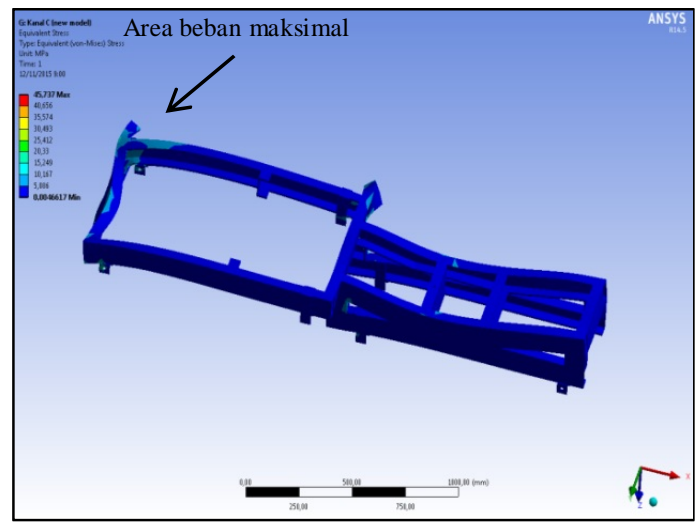

Gambar 7. Analisa pembebanan pada rangka C-channel section

Deformasi maksimal merupakan penyimpangan (deformasi) maksimal/terjauh yang terjadi pada rangka. Deformasi rangka $C$-channel sebesar 0,079 mm. Deformasi maksimal terjadi pada area berwarna merah (bagian melintang di bagian depan). Simulasi deformasi ditunjukkan Gambar 8. 


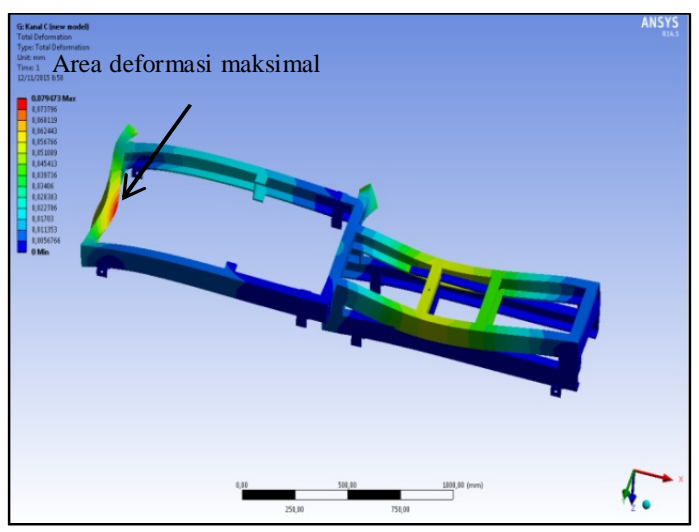

Gambar 8. Analisa deformasi pada rangka $C$ channel

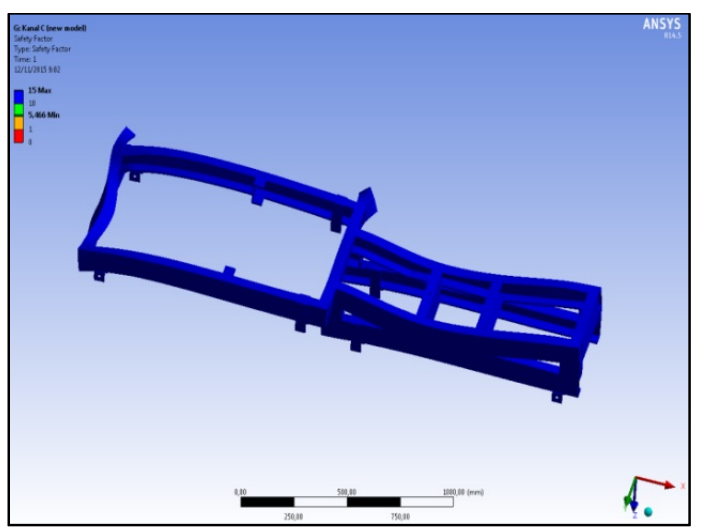

Gambar 9. Simulasi SF rangka dengan $C$ channel section

Gambar 9 menunjukkan analisa SF. SF rangka G-channel section sebesar 5,466. Rangka tersebut mampu menerima beban sebesar 5 kali dari beban yang diberikan pada simulasi ini.

Simulasi kedua diaplikasikan pada rangka dengan profil tubular section. Titik-titik pembebanan ditunjukkan Gambar 10. Berat rangka sebesar $46 \mathrm{~kg}$.

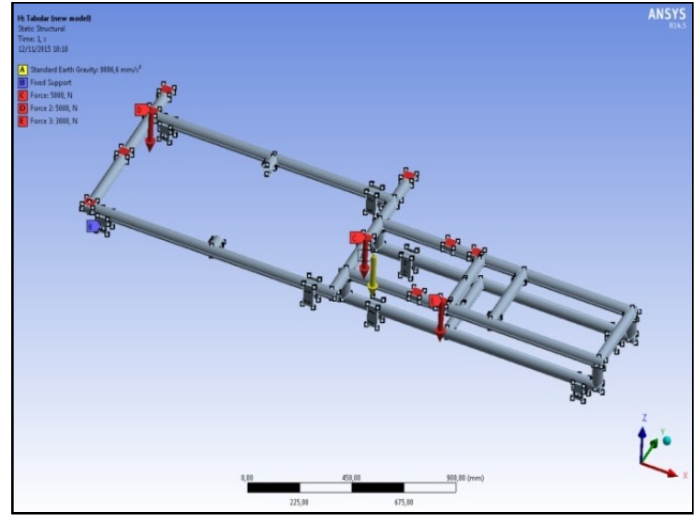

Gambar 10. Posisi titik-titik beban analisa pada rangka tubular section

Simulasi distribusi pembebanan pada rangka tubular bar ditunjukkan pada Gambar 11. Beban maksimal yang diterima oleh rangka sebesar 112 $\mathrm{MPa}$. Area yang menerima beban lebih besar antara lain pada di sudut bagian depan dan di antara sambungan bagian depan dan belakang.

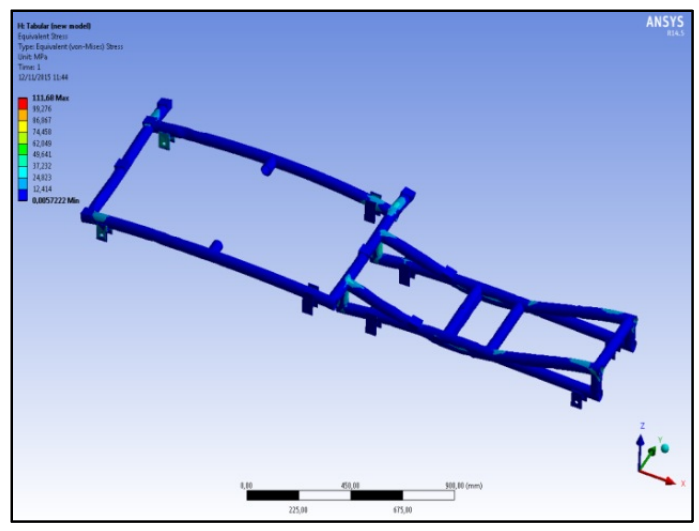

Gambar 11.Simulasi pembebanan pada sasis turbular section

Simulasi deformasi ditunjukkan Gambar 12. Deformasi maksimal sebesar $0,492 \mathrm{~mm}$. Area terjadinya deformasi maksimal terjadi pada area belakang rangka (warna merah). Simulasi SF ditunjukkan Gambar 13. SF rangka tubular section adalah 2,239. Rangka tersebut aman digunakan pada beban 2 kali dari beban yang diterima pada analisa ini. 



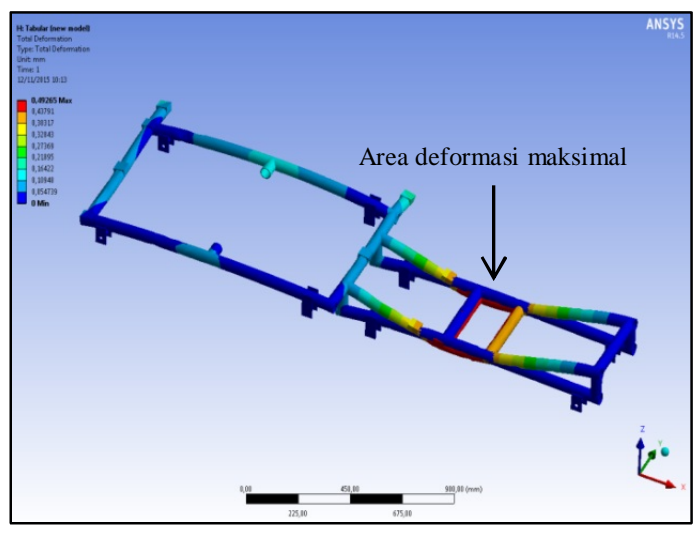

Gambar 12. Simulasi deformasi pada rangka dengan hollow tubular section

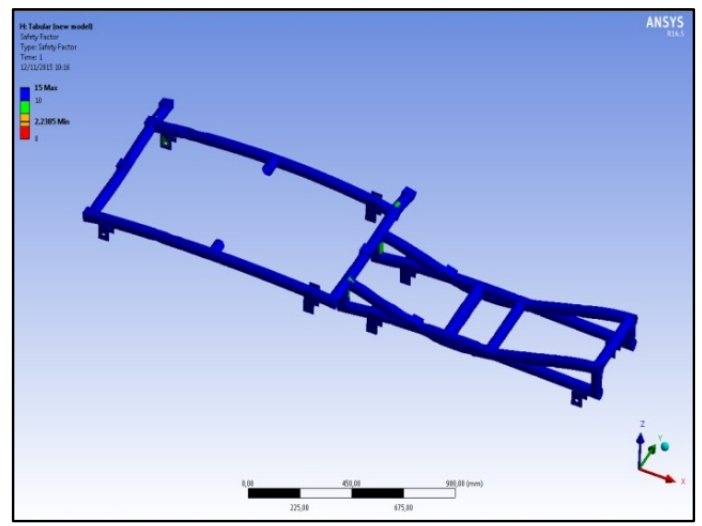

Gambar 13. Analisa SF pada rangka dengan hollow tubular section

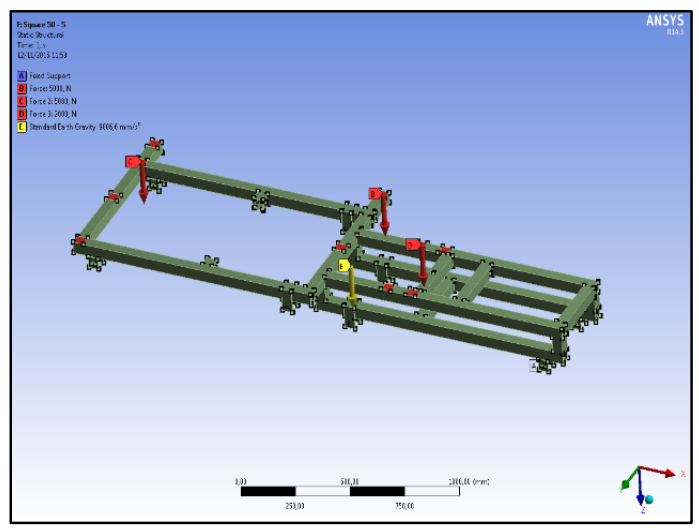

Gambar 14. Titik-titik pembebanan pada rangka dengan hollow square section

Simulasi ketiga dilakukan terhadap rangka dengan profil square section. Titik-titik pembebanan ditunjukkan Gambar 14. Berat rangka sebesar $76 \mathrm{~kg}$.

Simulasi distribusi pembebanan ditunjukkan oleh Gambar 15. Beban maksimal yang diterima oleh rangka adalah $55 \mathrm{MPa}$. Area yang menerima beban lebih besar antara lain bagian depan rangka.

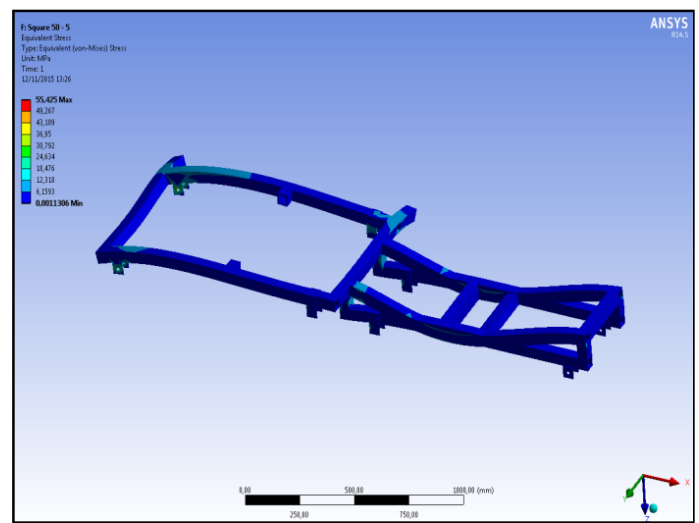

Gambar 15. Simulasi distribusi pembebanan pada rangka dengan profil hollow square section

Simulasi deformasi ditunjukkan oleh Gambar 16. Deformasi maksimal sebesar 0,1507 $\mathrm{mm}$. Area deformasi maksimal terjadi pada area berwarna merah.

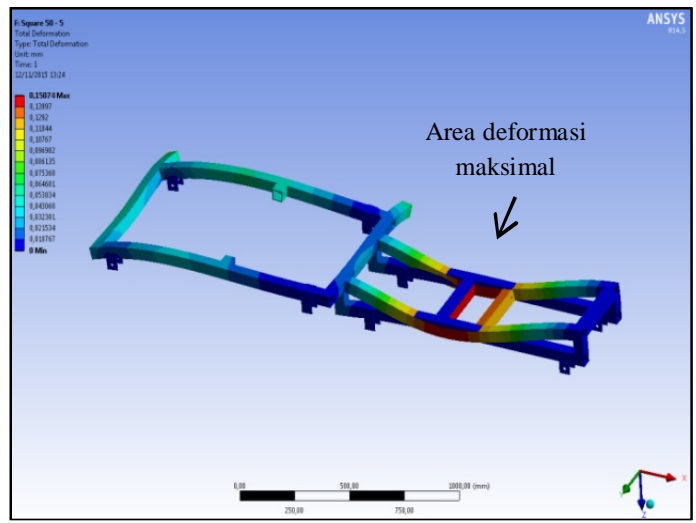

Gambar 16. Simulasi deformasi pada rangka square section

Simulasi SF ditunjukkan oleh Gambar 17. SF pada rangka hollow square sebesar 4,55. Rangka tersebut telah menggunakan 1/4 dari kapasitasnya terhadap beban yang diterima.

Tabel 3 menunjukkan rekaptulasi hasil scoring fabrikasi, simulasi distribusi pembebanan, deformasi dan SF. Masing-masing bentuk profil memiliki kelebihan dan kekurangan terhadap parameter analisa. Profil C-channel memiliki tingkat kemudahan fabrikasi dan SF yang baik namun memiliki berat yang besar. Profil tubular mudah difabrikasi dan memiliki berat yang ringan namun memiliki SF yang rendah. Profil hollow square lebih sulit difabrikasi namun memiliki 
berat yang memadai dan memiliki SF yang besar.

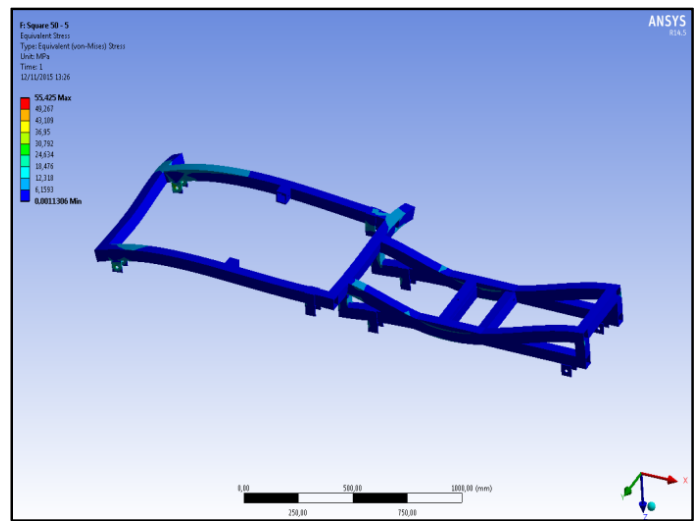

Gambar 17. Simulasi SF pada rangka dengan square section

Tabel 3. Rekapitulasi hasil analisa/simulasi

\begin{tabular}{|c|l|r|r|r|}
\hline No & \multicolumn{1}{|c|}{ Parameter } & \multicolumn{3}{|c|}{ Bentuk Profil } \\
\cline { 3 - 5 } & & C-channel & Tubular & $\begin{array}{l}\text { Hollow } \\
\text { Square }\end{array}$ \\
\hline 1 & $\begin{array}{l}\text { Scoring tingkat } \\
\text { kemudahan fabrikasi } \\
\text { terhadap kekuatan }\end{array}$ & 7 & 7 & 10 \\
\hline 2 & $\begin{array}{l}\text { Berat Rangka (kg); } \\
\text { dengan tebal 5 mm }\end{array}$ & 107 & 46 & 76 \\
\hline 3 & $\begin{array}{l}\text { Nilai maksimal beban } \\
\text { (Mpa) }\end{array}$ & 46 & 112 & 55 \\
\hline 4 & $\begin{array}{l}\text { Deformasi maksimal } \\
\text { (mm) }\end{array}$ & 0.079 & 0.492 & 0.151 \\
\hline 5 & SF & 5.43 & 2.23 & 4.55 \\
\hline
\end{tabular}

\section{KESIMPULAN}

Kesimpulan dari penelitian ini sebagai berikut:

1. Profil square merupakan bentuk profil yang paling mudah difabrikasi sedangkan profil kanal C dan tubular memiliki tingkat kesulitan yang sama.

2. Nilai deformasi terbesar terjadi pada profil tubular dan terkecil pada profil kanal C.

3. Rangka dengan kanal $\mathrm{C}$ menghasilkan rangka paling berat sedangkan rangka dengan tubular menghasilkan rangka paling ringan.

4. Rangka dengan safety factor terbesar dibuat dengan profil kanal $\mathrm{C}$ dan rangka dengan $\mathrm{SF}$ paling rendah dibuat dari profil tubular.

5. Rangka dengan profil square section merupakan model rangka dengan perpaduan berat dan SF memadai.

\section{UCAPAN TERIMA KASIH}

Ucapan terima kasih diberikan kepada Balai Besar Logam dan Mesin yang telah mendanai dan mendukung penelitian ini.

\section{DAFTAR PUSTAKA}

Al-Zaher, Abdo, and Waguih ElMaraghy. 2014. "Design Method of under-Body Platform Automotive Framing Systems." Procedia CIRP 17. Canada: Elsevier B.V.: 380-85. doi:10.1016/j.procir.2014.03.116.

Chen, Yanhong, and Feng Zhu. 2011. "The Finite Element Analysis and the Optimization Design of the Yj3128-Type Dump Truck's Sub-Frames Based on ANSYS." Procedia Earth and Planetary Science 2 (1). Kai Feng, China: Elsevier: 133-38.

doi:10.1016/j.proeps.2011.09.022.

Direktur Jenderal Tanaman Pangan. 2015. Pedoman Pelaksanaan Gerakan Penerapan Pengelolaan Tanaman Terpadu (GP-PTT). Jakarta: Kementerian Pertanian. doi:10.1017/CBO9781107415324.004.

Francis, Vishal, Rajnish Kumar Rai, Anup Kumar Singh, Pratyush Kumar Singh, and Himanshu Yadav. 2014. "Structural Analysis of Ladder Chassis Frame for Jeep Using Ansys." International Journal of Modern Engineering Research (IJMER) 4 (4). IJMER: 41-47.

http://www.ijmer.com/papers/Vol4_Issue4 /Version-5/IJMER-44054147.pdf.

Hemant B.Patil, Sharad D.Kachave, and Eknath R.Deore. 2013. "Stress Analysis of Automotive Chassis with Various Thicknesses." IOSR Journal of Mechanical and Civil Engineering (IOSR$J M C E) 6$ (1). India: IOSR-JMCE: 44-49. http://www.iosrjournals.org/iosrjmce/papers/vol6-issue1/G0614449.pdf.

Lin, Sin Liang, Bo Hao Huang, and Fuh Kuo Chen. 2014. "Strength and Formability Designs of Tube-Hydroformed Automotive Front Sub-Frame." Procedia Engineering 81 (October). Taipei, Taiwan: Elsevier B.V.: 2198-2204. doi:10.1016/j.proeng.2014.10.308.

Meier, Hubert, Ernst Ott, and Hinrich Haake. 1984. Corn Harvester. 4471788, issued 1984. http://patft.uspto.gov/.

Patel, Hirak, Khushbu C Panchal, and Chetan S 
Jadav. 2013. "Structural Analysis of Truck Chassis Frame and Design Optimization for Weight Reduction." International Journal of Engineering and Advanced Technology (IJEAT) 2 (4). IJEAT: 66568.

Patel, Tushar M, M G Bhatt, and Harshad K Patel. 2013. "Analysis and Validation of Eicher 11 . 10 Chassis Frame Using Ansys." International Journal of Emerging Trends and Technology in Computer Science (IJETTCS) 2 (2). India: IJETTCS: 10-13. www.ijettcs.org.

Ps, Madhu, and T R Venugopal. 2014. "Static Analysis, Design Modification and Modal Analysis of Structural Chassis Frame." International Journal of Engineering Research and Application 4 (5). India: IJERA: 6-10. www.ijera.com.

Sanjay, Salvi Gauri, Kulkarni Abhijeet, Gandhi
Pratik Pradeep, and P Baskar. 2014. "Finite Element Analysis of Fire Truck Chassis for Steel and Carbon Fiber Materials." International Journal of Engineering Research and Applications 4 (7). India: IJERA: 69-74. www.ijera.com.

Szulc, Maciej, Ireneusz Malujda, and Krzysztof Talaśka. 2016. "Method of Determination of Safety Factor on Example of Selected Structure." Procedia Engineering 136. Poznan, Poland: Elsevier B.V.: 50-55. doi:10.1016/j.proeng.2016.01.173.

Tayade, Vinayak R., and Avinash V. Patil. 2015. "Structular Analysis of Truck Chassis Using Finite Element Method." International Journal of Engineering Sciences \& Research \& Technology 4 (9). India: IJESRT: 721-28. www.ijesrt.com. 